\title{
IT-ITES trade of SAARC countries: does kaleidoscopic comparative advantage work?
}

\section{Nalin Bharti*, Kumar Gaurav and Chandan Kumar}

Department of Humanities and Social Sciences, Indian Institute of Technology Patna,

Amhara, Bihta 801103, Patna (Bihar), India

Email: nalinbharti@gmail.com

Email: nalinbharti@iitp.ac.in

Email: gauravsharan72@gmail.com

Email: kumargaurav@iitp.ac.in

Email: ck9973715@gmail.com

Email: chandan.phs13@iitp.ac.in

*Corresponding author

\begin{abstract}
Though, liberalisation of services trade is a new phenomenon, it has witnessed sustained growth and acceptance in recent decades. IT/ITES and its trade became the fastest growing sub-sector of trade in services. Services trade of SAARC countries became more dynamic in the post Uruguay Round. These economies are more integrated with the other economies of the world in services. Volatile comparative advantage with knife-edge specialisation pioneered the phrase, kaleidoscopic comparative advantage applicable equally to trade in services. In this backdrop, this study applied the qualitative (analysis of IT and telecommunications policy of all the SAARC countries) as well as quantitative methods (revealed comparative advantage - RCA index and services trade openness has been calculated) to capture the potentialities and competitiveness of IT/ITES trade of SAARC. This paper argues that the kaleidoscopic comparative advantage is not fixed only to bigger economies like India, but it has also extended to comparatively smaller economies like Sri Lanka, Bangladesh, and Pakistan.
\end{abstract}

Keywords: services trade; economic integration; Uruguay Round; liberalisation; IT/ITES; kaleidoscopic comparative advantage; SAARC; revealed comparative advantage; RCA.

Reference to this paper should be made as follows: Bharti, N., Gaurav, K. and Kumar, C. (2016) 'IT-ITES trade of SAARC countries: does kaleidoscopic comparative advantage work?', Int. J. Transitions and Innovation Systems, Vol. 5, No. 1, pp.80-96.

Biographical notes: Nalin Bharti is an Associate Professor and currently teaching economics at the Indian Institute of Technology Patna. Prior to joining IIT Patna, he has worked with NALSAR Law University (India's top Law School) and 12th Finance Commission, Government of India. His area of current research includes trade and economic reforms, intellectual property, WTO and India, and labour economics.

Kumar Gaurav is currently a Doctoral candidate in the Department of Humanities and Social Sciences, Indian Institute of Technology Patna. His ongoing Doctoral research is on India's involvement in Free Trade Agreement (FTA). 
Chandan Kumar is a Doctoral candidate in the Department of Humanities and Social Sciences, Indian Institute of Technology Patna and also awarded MPhil from the Ranchi University. His area of research is in the field of agriculture trade and India.

\section{Introduction}

Globalisation offers different hopes to different economies. However, economic globalisation is the consolidation of national economies into international economies through economic measures such as trade and investments. Services are a range of heterogeneous economic activities, which includes infrastructural services, social services, financial services, technological services, marketing services, commercial services, professional services, governmental services and personal services. Earlier services were regarded as non-tradable, non-transportable and non-scalable. However, today, it has resulted in important part of giant global businesses. Trade in services deals with the international transactions in services between residents of two or more countries. The cause behind the services trade is similar to trade in goods. The comparative cost advantage pioneered by Ricardo explains why trade in services is happening among nations. A country is said to have a comparative advantage in any good or service if the opportunity cost of production is lower in the home country than other countries (Krugman and Obstfeld, 2013). However, the comparative advantage has become competitive in the sense that huge margins which existed earlier in comparative advantage have now vanished (Bhagwati, 2008). The volatility in international trade distinguished by the changing pattern and degree of comparative advantage is no longer fixed, but instead it has become knife-edge. Bhagwati (2008) noted this unpredictability of comparative advantage and fluctuations in specialisation among countries, which is called kaleidoscopic comparative advantage. It can be believed that competition may arise from emerging economies like India and China, but every country is working to become competitive and may potentially emerge as a leader in one sector or the other. This phenomenon can equally be applied to services sector as well. The liberalisation of trade in goods has a long history, services liberalisation started only at the end of the Uruguay Round of the World Trade Organization (WTO) (Kelegama, 2009). The liberalisation of trade in services started among the WTO member countries in 1994 after the post Uruguay Round and later General Agreement on Trade in Services (GATS). This sets the multilateral rules for trade in services. The recent negotiations related to the multilateral framework of principles and rules should be made for sector-specific trade in services like telecommunications, civil aviation, shipping, etc. to make it more feasible (Nayyar, 2008). The rising demand for services has led to a shift from the industrial to services sector growth in many countries. The changing pattern of digitisation has too accelerated its demand where the information is transformed through a digital form by the use of information and communication technology (ICT). At present, the producers' behaviour has been modified by servicification process where non-services sectors (both agricultural and non-agricultural) in the economy buy and produce more services than before, and also sell and export more services (Aner and Rentzhog, 2014). This sector has played an important role in internationalising the supply chains and bringing efficient 
production. The growth of services is often related with growing investment in intangible assets like computerised information, innovative property, and economic competence. There is need of developing quality services capabilities at the competitive cost to make the global value chain economically viable and upgradable.

Today, services sector is regarded as an engine of growth in South Asia, where the 3Ts: technology, transportability and tradability has permitted significant product divisibility and tradability in this sector (Ghani, 2010). Services sector in South Asia outmatched merchandise and other sectors, showing higher and sustained growth during the last two decades (Chanda, 2011b). Services such as telecommunications, IT, and finance have experienced the most liberalisation in the post 2000 period in this region. Information technology (IT) and information technology enabled services (ITES) today have become one of the most important services. IT services are related to computer software, whereas ITES uses computers or telecommunications to render services to non-IT sectors, which may include insurance, banking, finance and others (Taneja et al., 2014). IT and ITES have received targeted attention and has become an integral part of the skill development and capacity building strategy in South Asia due to the rapidly growing demand for labour in this subsector (Chanda, 2011a). The promotion of competition is the most established way to promote telecommunication development as it promotes more services at lower prices and higher investment (Cecot and Wallstren, 2010). In this backdrop, this study highlights the comparative advantages of the South Asian countries in IT and ITES and tries to examine the nature of kaleidoscopic comparative advantage.

\section{Research methodology}

Finding dynamic kaleidoscopic comparative advantage in smaller economies of SAARC region is the prime motive of this paper. Research methodology (RM) of this study is primarily based on empirical estimation but qualitative techniques are also used to critically appraise the IT policies of SAARC countries. Empirical estimation includes computation of revealed comparative advantage (RCA) index and services trade openness. The strong export sectors of a country can be determined by different indices and methods. One of the major indices to verify a country's substantially strong and important sector for international trade can be measured through RCA index or Balassa (1965) index. It captures the degree of specialisation in a particular export sector. It is determined by the share of sector/industry $\mathrm{j}$ in country i's export divided by the share of sector/industry $\mathrm{j}$ in world exports. If the value of RCA index is greater than 1, country is said to have a comparative advantage in that sector or industry. RCA index is an ex-post method, which uses actual export data to calculate the values. RCA index suffers from certain limitations. This index can capture the degree of actual competitiveness only in the free trade scenario. As services trade is mainly decide by non-tariff barriers, the result of this index becomes infirm and will only highlight the potential sectors (Taneja et al., 2014). The RCA for computer and information services for the SAARC economies is calculated with the help of equation (1):

$$
\mathrm{RCAij}=(\mathrm{Xij} / \mathrm{Xi}) /(\mathrm{Xaj} / \mathrm{Xa})
$$


where $\mathrm{Xij}=$ exports of service $\mathrm{j}$ from country $\mathrm{i}, \mathrm{Xi}=$ total exports from country $\mathrm{i}$, $\mathrm{Xaj}=$ total exports of service $\mathrm{j}$ from the world, and $\mathrm{Xa}=$ total services export from the world.

As RCA of services trade works more positively in a liberalised trade framework, the RM cannot say to be complementary to RCA index of IT-ITES services in SAARC without estimating the trade openness scenario of SAARC countries in services. Trade openness index captures the degree of liberalisation of an economy by understanding the contribution of trade in GDP. Trade openness index measured in this paper is highlighting service trade openness so services trade to GDP ratio is calculated through the following equation:

$$
\mathrm{T}=[(\mathrm{Xs}+\mathrm{Ms}) / \mathrm{GDP}] \times 100
$$

where $\mathrm{Xs}=$ exports of services, $\mathrm{Ms}=$ imports of services, and GDP $=$ gross domestic product.

Apart from the empirical estimation, the IT and telecom policies of SAARC economies are also imperative to cross verify the validity of the empirical results. Table 3 and Table 4 present a comparative policy variations and reforms of SAARC countries.

\section{Telecom and IT: policy and growth in South Asia}

Economic reforms were initiated mainly in the 1980s in the South Asia. Sri Lanka was one of the first countries in this region to initiate the reforms process back in 1977, followed by Bangladesh in 1980s, Nepal in mid-1980s, Pakistan in 1988, Maldives in 1989, and India in 1991. The reforms and liberalisation of the domestic economies in the South Asian region paved the ways for liberalisation of telecom and IT sectors which was complied in Table 4. The outcome of reforms in IT and telecommunications was evident through the increased tele-density and later an increase in the cellular mobile users in the SAARC region. In 1981, South Asia had a fixed-line tele-density of 0.31 , which increased to 0.65 in 1991. Another decade later, this tele-density had increased by over fivefold, reaching 3.2. Despite South Asia's high telecommunication growth rate over years, the official waiting list for a fixed telephone line did not decrease significantly. During the period, 1996 to 2001, while main telephone lines in operation in South Asia grew at $20 \%$ a year, waiting lists decreased by only $7 \%$ a year. Overall, South Asia's waiting list stood at 2.6 million at the end of 2001, down from 3.8 million at the end of 1996. The phenomenon of mobile phones surpassing fixed telephone lines has not yet generally occurred in South Asia, except in Bangladesh and the Maldives. Ironically, the former has the region's lowest fixed-line tele-density while the latter has the highest. In the Maldives, mobiles could be said to have been supplementing fixed lines. Mobile tariffs are relatively high and fixed lines are available on demand on densely populated islands. The introduction of pre-paid service in September 2001 has begun to shift mobile demand from supplement to substitute. In Bangladesh, where there are few fixed telephone lines relative to the population, mobiles are a substitute for telephone service. Telecommunication infrastructure of South Asia is not as lacking as many make it out to be. During the past five years, there has been an unprecedented growth in telecommunications network in the region. Table 1 and Table 2 show tele-density and mobile-cellular telephone subscriptions for SAARC countries during 2000 to 2014. 
Table 1 Tele-density in SAARC countries

\begin{tabular}{lcccc}
\hline Country & 2000 & 2005 & 2010 & 2014 \\
\hline Afghanistan & 0.14 & - & 0.06 & 0.33 \\
Bangladesh & 0.37 & 0.75 & 0.85 & 0.61 \\
Bhutan & 2.51 & 5.07 & 3.67 & 3.11 \\
India & 3.11 & 4.45 & 2.91 & 2.13 \\
Maldives & 8.96 & 10.85 & 8.71 & 6.11 \\
Nepal & 1.15 & 1.92 & 3.14 & 2.98 \\
Pakistan & 2.12 & 3.31 & 3.51 & 2.65 \\
Sri Lanka & 4.07 & 6.24 & 17.24 & 12.49 \\
\hline
\end{tabular}

Source: ITU (2016a)

Table 2 Mobile-cellular telephone subscriptions per 100 inhabitants

\begin{tabular}{lcccc}
\hline Country & 2000 & 2005 & 2010 & 2014 \\
\hline Afghanistan & 0 & 4.83 & 45.78 & 74.88 \\
Bangladesh & 0.21 & 6.29 & 44.95 & 80.04 \\
Bhutan & 0 & 5.53 & 55.00 & 82.07 \\
India & 0.34 & 8.00 & 62.39 & 74.48 \\
Maldives & 2.80 & 68.43 & 151.78 & 189.38 \\
Nepal & 0.04 & 0.90 & 34.25 & 81.87 \\
Pakistan & 0.21 & 8.08 & 57.28 & 73.33 \\
Sri Lanka & 2.28 & 16.85 & 83.62 & 103.16 \\
\hline
\end{tabular}

Source: ITU (2016b)

Practically, all inhabitants of urban areas have access to telephone service. For example, India reports that all of its some 5,000 cities and towns have access to the telephone network. Sri Lanka notes that telephones are available on demand in all its cities. This suggests that about $28 \%$ of South Asia that is classified as urban has access to telephone service. There has also been improvement in rural access to telecommunications. Roughly, $80 \%$ of the rural population has access to basic telephone services and over $50 \%$ of the population is covered by mobile signal. All together, over one billion inhabitants of South Asia, or $88 \%$ of the population, have access to telephone service.

Telecommunication was the part of the public monopoly, but the voice to liberalise this sector has become the part of the economic reforms process in South Asia. Mukherji (2001) noted the global demand for liberalising this sector, which was quite natural. The growth of telecommunications in all South Asian countries started as a state-sponsored activity - both because of the need to support heavy investment and exercise control over them. However, very rapid advances in technology have constrained the capacity of governments to supply quality services. This has clearly demonstrated the need for greater flexibility and initiative, which the private sector alone is capable of performing. There is, hence, the need to facilitate greater private sector initiative while at the same time ensuring a healthy regulatory framework that could ensure that public monopolies do not transform to private ones. 
Table 3 IT policy of SAARC countries: a comparison

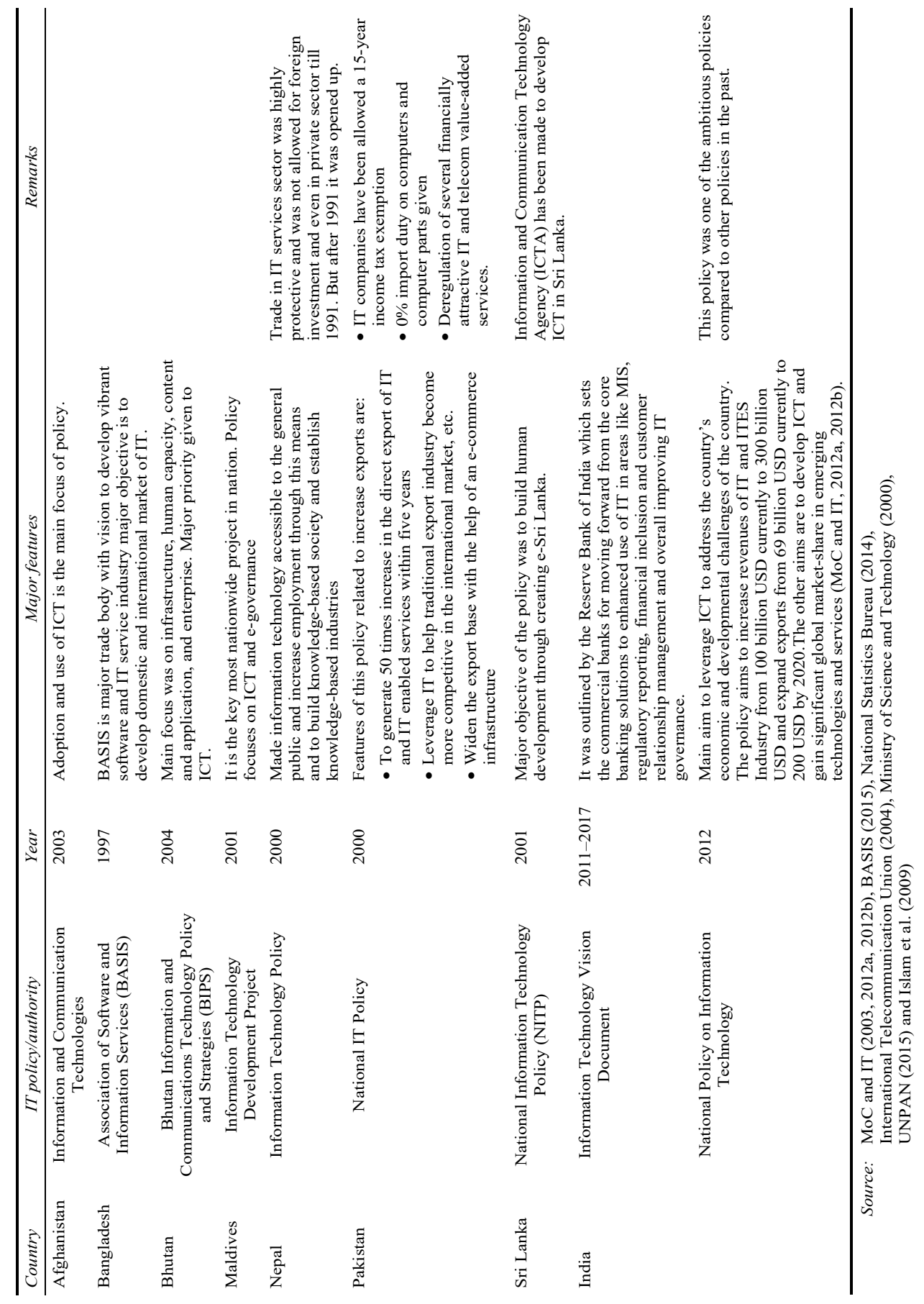


Table 4 Telecommunications policy of SAARC countries

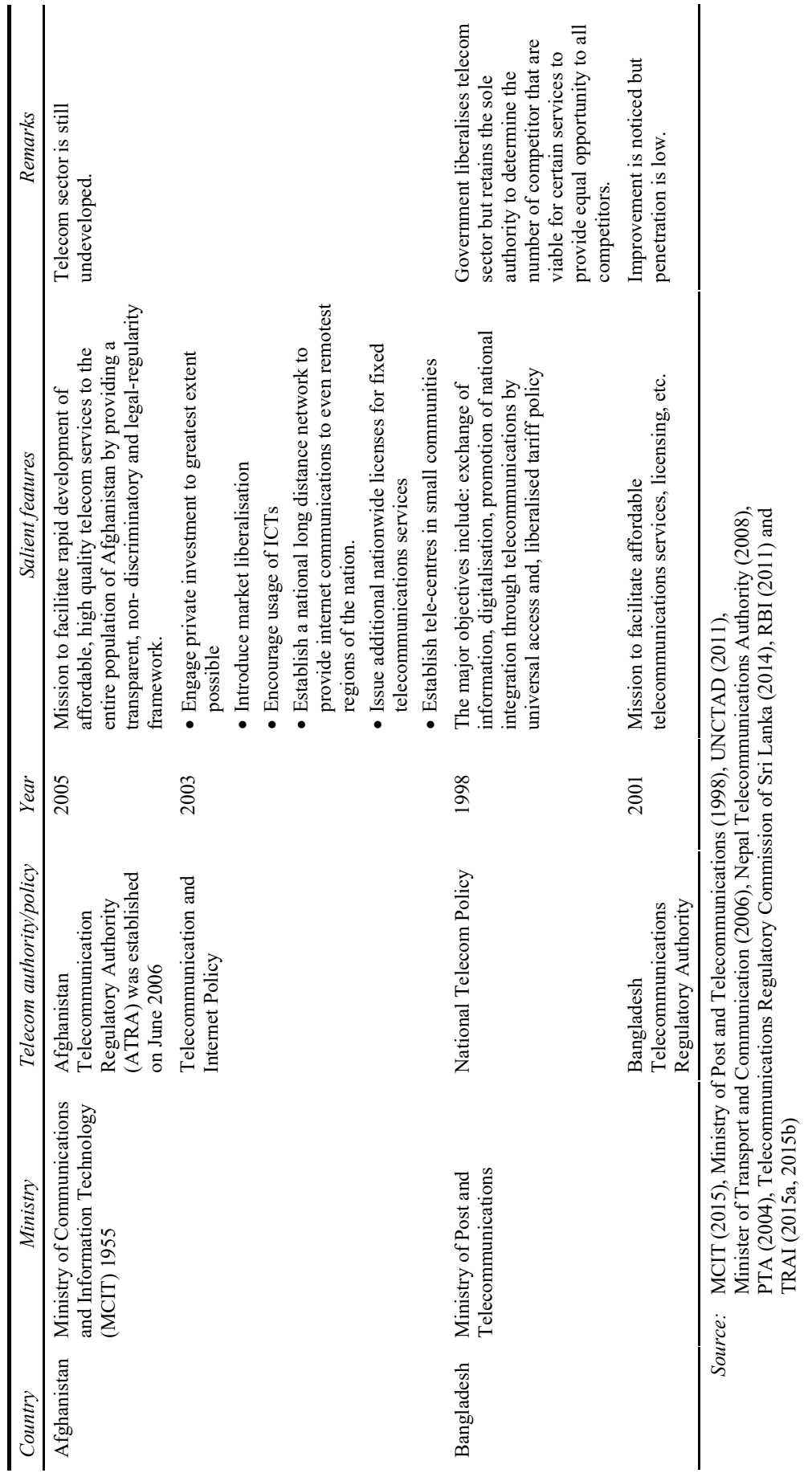


Table 4 Telecommunications policy of SAARC countries (continued)

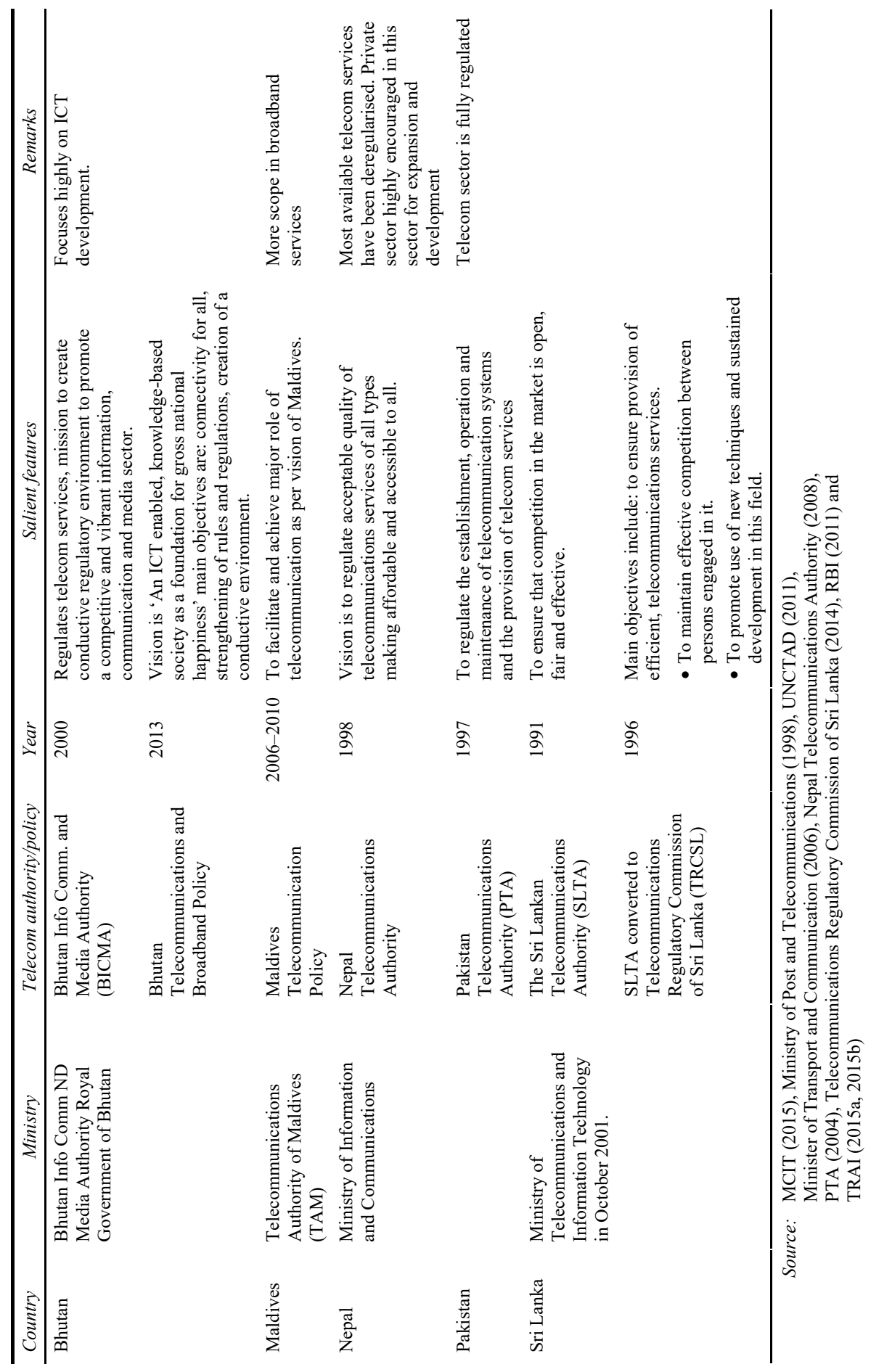


Table 4 Telecommunications policy of SAARC countries (continued)

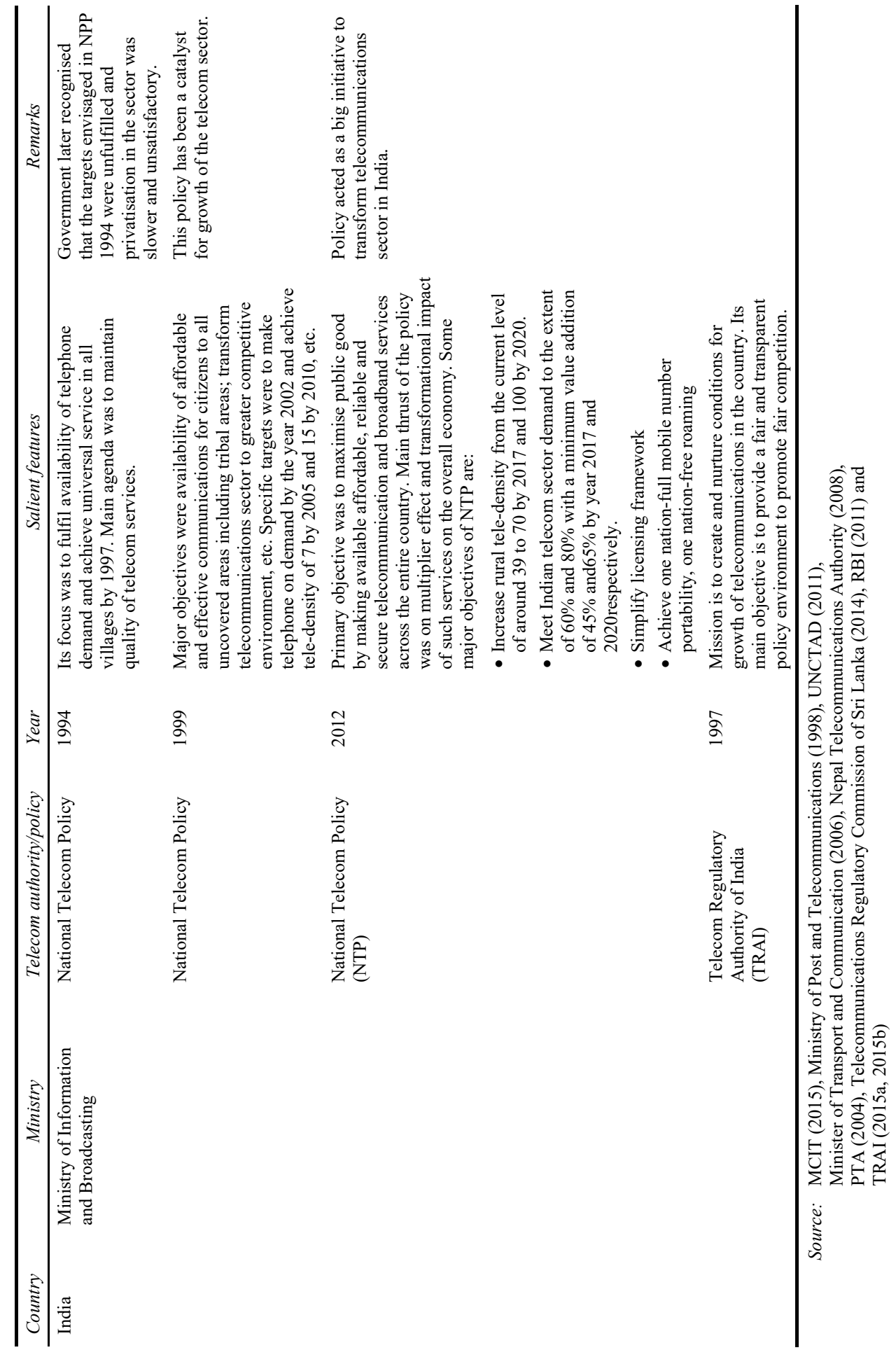


Holsman (1997) noticed that industries such as telecommunications, finance and energy were being restructured to respond to the needs of an integrated world economy. The global structure of these industries demands their participation in the privatisation process. World Bank (1999) too admitted that the WTO's GATS brought the service sector, together with telecommunication, into multiparty trade negotiations. Around $90 \%$ of the worldwide telecommunications market representing sixty-nine WTO members had committed to liberalise basic telephone services. Thirty-one industrial and 24 developing economies also made commitments to liberalise their voice telephone services. There were other obligations to liberalise long-distance international calls and voice telephony, data transmission, private leased circuits, mobile and satellite services, and trunk services. This is the first instance in the world when economies realised to exploit the benefits of better competitiveness, improved foreign direct investment (FDI), and an enhanced price-quality mix of subscriber's services. These benefits were calculated in an environment when telecommunication had a quite inefficient and under investment market condition.

The South Asian economies as a part of GATS started reforming its telecom sector with more private investment and competition among the service providers. Table 3 and Table 4 highlight such reforms in individual counties. From the tables, it is clear that a new regime of telecommunication has begun in South Asia. Most of the nations have established a telecom regulatory board and the investors have started looking for the upcoming South Asian markets. The common picture, which emerges from the above analysis on regulation and competition, is that the most of the countries have liberalised their markets with diverse sets of investors in these countries. The telecom market in India and Pakistan is less liberalised compared to Bangladesh, which has allowed 100\% private participations in mobile cellular sectors. Sri Lanka, Nepal, Bhutan, and Afghanistan have also started competitive environment with the support of some foreign partners. These reforms prepared South Asian economy in integrating with the global economy, especially for IT and ITES trade.

Moreover, global services location index (GSLI) ${ }^{1}$ computed by AT Kearney also highlight the countries with potential as well as performance in delivering services offshore. Table 5 shows GSLI rank for selected SAARC countries during 2011 to 2014. Apart from India, Sri Lanka and Bangladesh have shown tremendous potential in supply of services offshore and thus, their rank has been improving in the GSLI. Pakistan's ranking however, declined in 2014.

Table 5 Rank in GSLI of major SAARC countries

\begin{tabular}{lccc}
\hline Country & 2011 & 2014 & 2016 \\
\hline India & $1(0)$ & $1(0)$ & $1(0)$ \\
Sri Lanka & 21 & $16(+5)$ & $14(+2)$ \\
Pakistan & 28 & $25(-3)$ & $28(+3)$ \\
Bangladesh & - & 26 & $22(+4)$ \\
\hline
\end{tabular}

Note: Figures in the brackets show decline $(-)$ /increase $(+)$ from the previous reported year rank.

Source: AT Kearney $(2011,2014,2016)$ 


\section{Services trade openness and export share of SAARC countries}

Trade liberalisation in the services sector is comparatively new and South Asia inked Agreement on Trade in services in April 2010 in Thimpu. This Agreement is called 'SAARC Agreement on Trade in Services' and it came into force on November 29, 2012. This opened the new avenue for services trade in this region. This initiative has affected the services trade in South Asia with more liberalised economies ready to reap the comparative advantage in one or the other sector. Economic openness is not simply confined to trade flows, investment flows and financial flows. It also expands to flows of services, technology, information and ideas across national boundaries. The internationalisation of services has made a profound impact on the output, employment and trade in the world economy. Table 6 shows services trade openness ${ }^{2}$ for all the SAARC countries for 2000 to 2012. There has been an increase in services' openness for all the SAARC countries during 2000 to 2012. India's services trade openness has increased from $6 \%$ in 2000 to almost $20 \%$ in 2012, showing more than three times increase. Pakistan's services trade openness also improved three times. Sri Lanka and Nepal's services trade openness has moderately increased during this period, while Bhutan and Bangladesh's openness almost doubled. Maldives services trade openness was very high, which is the outcome of tourism. Afghanistan's services trade openness also showed improvement during this period.

Table 6 Services trade openness for SAARC countries (in percentage)

\begin{tabular}{ccccccccc}
\hline Year & India & Sri Lanka & Pakistan & Bangladesh & Bhutan & Nepal & Maldives & Afghanistan \\
\hline 2000 & 6.00 & 12.77 & 3.94 & 4.79 & 11.82 & 10.10 & 54.23 & - \\
2001 & 5.95 & 15.71 & 4.03 & 4.25 & 11.01 & 8.54 & 53.17 & - \\
2002 & 6.21 & 13.87 & 4.81 & 4.03 & 12.27 & 7.36 & 51.47 & - \\
2003 & 6.89 & 14.18 & 6.15 & 4.63 & 17.76 & 8.34 & 51.77 & - \\
2004 & 9.65 & 14.95 & 7.39 & 4.82 & 17.03 & 10.60 & 55.44 & - \\
2005 & 11.92 & 14.87 & 9.50 & 5.22 & 20.80 & 9.87 & 49.13 & - \\
2006 & 14.03 & 15.29 & 9.54 & 5.20 & 12.88 & 10.30 & 58.73 & - \\
2007 & 15.70 & 15.60 & 9.61 & 5.97 & 11.37 & 13.90 & 61.16 & - \\
2008 & 18.73 & 16.86 & 10.49 & 7.07 & 13.70 & 16.80 & 64.42 & - \\
2009 & 15.25 & 14.34 & 7.66 & 6.35 & 13.44 & 15.80 & 123.60 & 27.06 \\
2010 & 18.49 & 16.80 & 9.83 & 7.58 & 16.22 & 15.00 & 134.69 & 42.22 \\
2011 & 19.79 & 19.71 & 9.08 & 8.05 & 18.60 & 15.50 & 139.84 & 42.18 \\
2012 & 19.72 & 16.55 & 10.09 & 8.08 & 20.46 & 16.30 & 125.94 & - \\
\hline \multicolumn{7}{c}{ Source: } & Authors' calculation based on data available from ITC (2015) and &
\end{tabular}

Computer and Information Services in South Asia are dominated by India through IT and ITES. This sector has made India an undisputed leader not only in this region, but also in the world. Figure 1 shows India's export share of computer and information services to world exports (in \%) on the primary vertical axis. All other line diagrams (for Sri Lanka, Pakistan, Bangladesh and Afghanistan) are represented on secondary vertical axis. India's share has continuously increased during 2000 to 2012 with slight declines. Sri Lanka's share of world exports has declined during 2000 to 2006 and then increased and was 
highest in 2012. Pakistan and Bangladesh almost showed moderately increasing trends. Afghanistan's export share in computer and information services to world exports is almost negligible.

Figure 1 Exports share of SAARC countries in computer and information services to world exports (percentage) (see online version for colours)

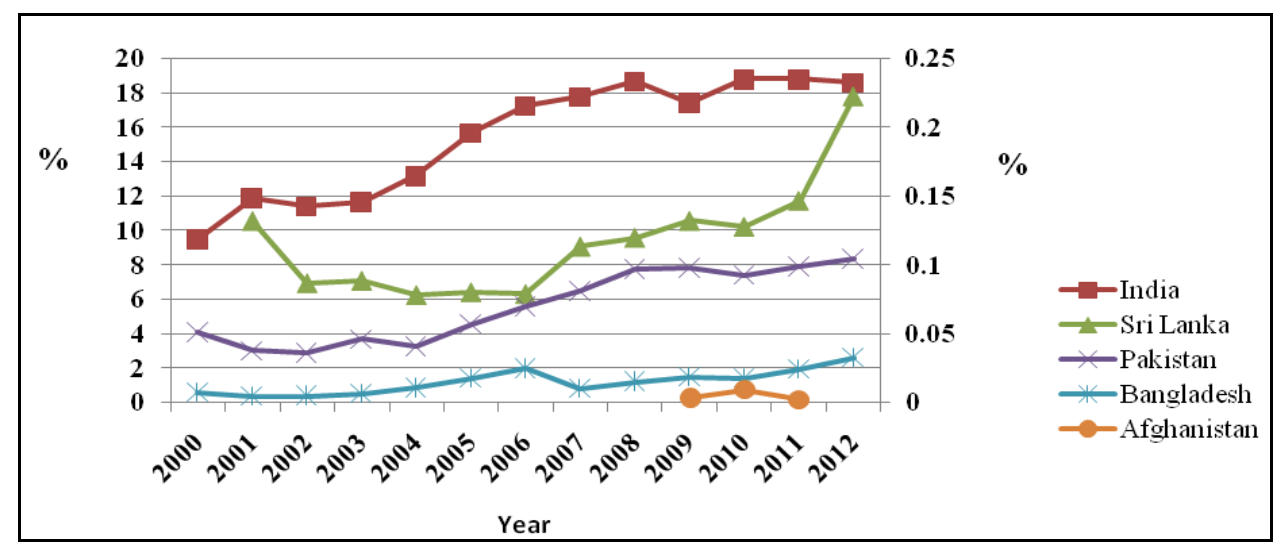

Source: Authors

\section{Results of RCA index for IT-ITES trade of SAARC economies}

South Asia is marked by large asymmetries among countries. India is the largest economy in this region, and the Maldives, Bhutan and Nepal are the smallest members in terms of GDP and size of the markets. India has been one of the fastest growing economies in the world after China. Services' growth in India is remarkable and India has emerged as the services giant in the world. India is the undisputed leader in IT/ITES with huge potentials in this sector. The degree of competitiveness of South Asian countries in services can be examined through RCA analysis (Kelegama, 2009). RCA has been calculated at the disaggregated level for computer and information services for India, Sri Lanka, Pakistan, Bangladesh and Afghanistan as shown in Table 7. The data for Nepal, Bhutan and Maldives are not available and Afghanistan's data are available for limited period (2009 to 2011). The table shows that for India, RCA has always been above unity during the reference period. It indicates that India has comparative advantage in computer and information services sector. This is competitive sector as far as exports of these services are concerned. In addition, India has specialisation in this sector. Sri Lanka has also shown RCA greater than unity during the same period, though the values are below that of India. Other countries (Pakistan, Bangladesh and Afghanistan) have RCA below unity. One of the major concerns for India is that the RCA values are declining with ups and downs, on the other hand Sri Lanka's RCA is improving with moderate fluctuations. Therefore, it can be said that Sri Lanka is emerging as a potential competitor for India in computer and information services sector. Sri Lanka has recently emerged as a favourite destination for IT and BPO services provider. Moreover, in the year 2011, Sri Lanka was placed at 21st position in the AT Kearney's GSLI, which improved to five positions in 2014 , and it was placed at 16 th position. More recently, in 
2016, Sri Lanka's position in the GSLI was 14th. This shows its strength as a favourite location for offshore operations by different companies. According to AT Kearney (2012), Sri Lanka's strength for IT, BPO and knowledge services outsourcing (LPO) is its cost-competitive environment for business, highly skilled English speaking work force, and good infrastructure. Statistics show that large number of global IT and BPO companies are operating in Sri Lanka such as HP, IFS, HSBC, Motorola, etc. It has made its competitive position in financial and accounting outsourcing (FAO) services. Changes in the values of the services trade openness and the RCA index with time for the SAARC countries (as shown in Table 6 and Table 7) highlight the dynamic aspects and changing services trade landscape in these countries.

Table 7 RCA index for IT-ITES trade of SAARC countries

\begin{tabular}{cccccc}
\hline Year & India & Sri Lanka & Pakistan & Bangladesh & Afghanistan \\
\hline 2000 & 8.37 & - & 0.55 & 0.14 & - \\
2001 & 10.1 & 1.43 & 0.38 & 0.1 & - \\
2002 & 9.61 & 1.12 & 0.25 & 0.11 & - \\
2003 & 9.28 & 1.19 & 0.3 & 0.13 & - \\
2004 & 7.94 & 1.18 & 0.35 & 0.24 & - \\
2005 & 7.68 & 1.34 & 0.4 & 0.38 & - \\
2006 & 7.18 & 1.41 & 0.58 & 0.55 & - \\
2007 & 7.14 & 2.23 & 0.76 & 0.22 & - \\
2008 & 6.84 & 2.35 & 0.9 & 0.31 & - \\
2009 & 6.7 & 2.48 & 0.88 & 0.34 & 0.07 \\
2010 & 6.26 & 2.01 & 0.55 & 0.29 & 0.12 \\
2011 & 5.91 & 2.08 & 0.86 & 0.45 & 0.03 \\
2012 & 5.67 & 2.61 & 0.71 & 0.56 & - \\
\hline
\end{tabular}

Source: Authors' calculation based on data available from ITC (2015)

One of the major benefits for countries that are located in the vicinity of large highly developing or developed countries is the spillover effects of development that eventually gets experienced in those under-developed countries. Proximity of Sri Lanka to India and similar efficiency and cost environment, Sri Lanka is today seen by the global companies as a natural complement to their Indian off-shore operations. Similar benefits can be tapped by Pakistan as well as Bangladesh. These economies have the potential to emerge as favourite destinations for IT, ITES and other offshore services.

\section{Conclusions}

Economic integration through services trade is relatively a new phenomenon compared to trade in goods in the post GATS years. South Asian economies as a whole and at the individual level are now more liberalised as far as services trade is concerned. From the trade openness indicator for liberalisation, it is evident that services trade openness of India and Pakistan has increased three times during 2000 to 2012. Sri Lanka and Nepal's services trade openness has moderately increased during this period, while Bhutan's and Bangladesh's service trade openness almost doubled. Maldives services trade openness 
was very high, which is the outcome of tourism. Afghanistan's services trade openness also showed improvement during this period. IT/ITES has become one of the fastest growing sectors in the world. India's export share in computer and information services, fuelled with IT/ITES has continuously increased during 2000 to 2012 with slight declines. Sri Lanka's share of world exports has declined during 2000 to 2006 and then increased. Pakistan and Bangladesh's share almost showed moderately increasing trends. Afghanistan's export share in computer and information services to world exports is almost negligible. The RCA for India has always remained above unity during the reference period. It indicated that India holds the comparative advantage in computer and information services sector. This is competitive sector as far as exports of these services are concerned. In addition, India has specialisation in this sector. Sri Lanka's RCA is also greater than one during the same period, though the values are below that of India. Other countries such as Pakistan, Bangladesh and Afghanistan's RCA is below unity. One of the major concerns for India is that the RCA values are declining with moderate fluctuations during 2000 to 2012, on the other side, Sri Lanka's RCA is improving with moderate fluctuations. Therefore, it can be said that Sri Lanka has the potential in computer and information services sector. The paper concludes that other South Asian countries like Pakistan and Bangladesh also have the potential to become leaders in IT and ITES services categories in the world.

The advantage for India in IT/ITES is linked to the policy reforms, regulatory mechanisms and international competitiveness, which is more proactive, compared to other economy of South Asia as evident in Table 3 and Table 4. South Asian countries are opening their economies to services trade and have the potential to compete in different services at the disaggregated level. Apart from India's performance as a bigger economy, comparatively smaller SAARC economies, such as Sri Lanka, Bangladesh and Pakistan are also enjoying unpredictable comparative advantage in a more integrated world. This shows functioning of kaleidoscopic comparative advantage in South Asia.

\section{Acknowledgements}

The authors acknowledge language editor of this paper Ms. Sadeqa Ghazal for improving the quality of this paper.

\section{References}

Aner, E. and Rentzhog, M. (2014) The New Services Era - Is GATS up to the Task? The E15 Initiative [online] http://e15initiative.org/publications/the-new-services-era-is-gats-up-to-thetask/ (accessed 15 January 2015).

AT Kearney (2011) A.T. Kearney Global Services Location Index: Off shoring Opportunities amid Economic Turbulence [online] https://www.atkearney.com/documents/10192/373096/ Offshoring_Opportunities_Amid_Economic_Turbulence-GSLI_2011.pdf/f062cfd8-ee984312-ae4f-0439afc10880 (accessed 22 April 2016).

AT Kearney (2012) Competitive Benchmarking: Sri Lanka Knowledge Services [online] http://www.atkearney.in/documents/10192/430128/Country_Competitiveness_StudySri_Lanka.pdf/7d3033a4-5935-41d8-bf99-a1462bf7d553 (accessed April 22 2016).

AT Kearney (2014) The 2014 A.T. Kearney Global Services Location Index: A Wealth of Choices from Anywhere on Earth to No Location At All [online] https://www.atkearney.com/ 
documents/10192/5082922/A+Wealth+of+Choices.pdf/61c80111-41b2-4411-ad1edb4a3d6d5f0d (accessed 22 April 2016).

AT Kearney (2016) 2016 A.T. Kearney Global Services Location Index: On the Eve of Disruption [online] http://www.atkearney.in/documents/10192/7094247/On+the+Eve+of+Disruption.pdf/ 49fa89fa-7677-4ab8-8854-5003af40fc8e (accessed 22 April 2016).

Balassa, B. (1965) 'Trade liberalization and revealed comparative advantage', The Manchester School, Vol. 33, No. 2, pp.99-123.

Bangladesh Association of Software and Information Services (BASIS) (2015) About BASIS, Dhaka [online] http://www.basis.org.bd/index.php/about (accessed 20 March 2015).

Bhagwati, J. (2008) In Defense of Globalization, Oxford University Press, New Delhi.

Cecot, C. and Wallstren, S. (2010) 'South Asian telecommunications development and the role of regional cooperation', in Ghani E. (Ed.): The Service Revolution in South Asia, Oxford University Press, New Delhi.

Chanda, R. (2011a) Impact of Services Trade Liberalization on Employment and People Movement in South Asia, WP 339, Asian Development Bank Institute, Tokyo [online] http://www.adbi.org/files/2011.12.30.wp339.employment.impact.services.trade.south.asia.pdf (accessed 5 January 2015).

Chanda, R. (2011b) Integrating Services in South Asia: Trade, Investment, and Mobility, Oxford University Press, New Delhi.

Ghani, E. (2010) The Service Revolution in South Asia, Oxford University Press, New Delhi.

Holsman, H. (1997) The roots of Privatization: Briefing Notes for Current Debates on Public Sector Issues, Public Service International, Ferney-Voltaire.

International Telecommunication Union (2004) Information and Communication Technology in the Atolls: Maldives Case Study, Geneva [online] https:/www.itu.int/ITU-D/ict/cs/maldives/ material/CS_MDV.pdf Telecomm Policy (accessed 22 March 2015).

International Telecommunication Union (ITU) (2016a) Fixed-telephone Subscriptions, Geneva [online] https://www.itu.int/en/ITU-D/Statistics/Pages/stat/default.aspx (accessed 27 April 2016).

International Telecommunication Union (ITU) (2016b) Mobile-cellular Subscriptions, Geneva [online] https://www.itu.int/en/ITU-D/Statistics/Pages/stat/default.aspx (accessed 27 April 2016).

International Trade Centre (ITC) (2015) Market Analysis and Research, Geneva [online]

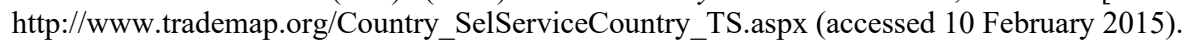

Islam, M.A., Murelli, E., Noronha, F. and Rahman, H. (2009) 'Capacity development initiatives for marginal communities: a few case studies', in Rahman, H. (Ed.): Selected Readings on Global Information Technology: Contemporary Applications, Information Science Reference, p.125, New York.

Kelegama, S. (2009) Trade in Services in South Asia, Sage, New Delhi.

Krugman, P.R. and Obstfeld, M. (2013) International Economics: Theory and Policy, Pearson, New Delhi.

Minister of Transport and Communication (2006) Maldives Telecommunication Policy 2006-2010 [online] http://www.cam.gov.mv/docs/policy/Telecom_policy_2006_2010_Eng.pdf (accessed 10 March 2015).

Ministry of Communication and Information Technology (MoC and IT) (2003) Open Access Policy of the Afghanistan Ministry of Communication and Information Technology, MCIT, Islamic Republic of Afghanistan, Kabul [online] http://mcit.gov.af/Content/files/Open\%20Access\% 20Policy\%20of\%20the\%20Afghanistan_2(1).pdf (accessed 5 March 2015).

Ministry of Communication and Information Technology (MoC and IT) (2012a) Cabinet Approves National Policy on Information Technology 2012, Policy Aims to Leverage ICT to Address Nation's Developmental Challenges, Press Information Bureau, New Delhi [online] http://www.pib.nic.in/newsite/erelease.aspx?relid=87875 (accessed 12 January 2015). 
Ministry of Communication and Information Technology (MoC and IT) (2012b) National Telecom Policy 2012, TRAI, New Delhi [online] http://www.trai.gov.in/WriteReadData/userfiles/file/ NTP\%202012.pdf (accessed 2 March 2015).

Ministry of Communications and Information Technology (MCIT) (2015) Afghan Telecommunications Regulatory Authority (ATRA), Islamic Republic of Afghanistan, Kabul [online] http://mcit.gov.af/en/page/80 (accessed 20 February 2015).

Ministry of Post and Telecommunications (1998) National Telecommunications Policy 1998, Dhaka [online] http://www.btrc.gov.bd/sites/default/files/Telecom_Policy.pdf (accessed 6 March 2015).

Ministry of Science and Technology (2000) Information Technology Policy, 2057 [online] Department of Information Technology (DoIT), Government of Nepal, Kathmandu. moste.gov.np/it_policy_2057_(2000_ad) (accessed 18 March 2015).

Mukherji, I.N. (2001) 'Information technology in South Asian growth quadrangle: possibilities for regional cooperation', in Lama, M.P. (Ed.): South Asian Growth Quadrangle: Emerging Opportunities for Economic Partnership, p.79, FICCI, New Delhi.

National Statistics Bureau (2014) Statistical Year Book of Bhutan, Royal Government of Bhutan, Thimphu [online] http://www.nsb.gov.bt/publication/files/pub8sf8803mf.pdf (accessed 1 March 2015).

Nayyar, D. (2008) Trade and Globalization, Oxford University Press, New Delhi.

Nepal Telecommunications Authority (2008) Management Information System, Kathmandu [online] http://www.nta.gov.np/en/2012-06-01-11-33-01/mis-archives/mis.../nta.../download (accessed 20 January 2015).

Pakistan Telecommunication Authority (PTA) (2004) Government of Pakistan, Islamabad [online] $\mathrm{http}$ ://www.pta.gov.pk/index.php?option=com_content\&view=article\&id=359\&Itemid=325 (accessed 14 March 2015).

Reserve Bank of India (RBI) (2011) IT Vision of Reserve Bank of India, Mumbai [online] http://www.rbi.org.in/scripts/PublicationVisionDocuments.aspx?Id=629 (accessed 12 January 2015).

Taneja, N., Nagpal, N.K. and Ray, S. (2014) India-Korea CEPA: Harnessing the Potential in Services, Indian Council for Research on International Economic Relations, ICRIER WP 280.

Telecom Regulatory Authority of India (TRAI) (2015a) New Telecom Policy, New Delhi [online] http://www.trai.gov.in/Content/ntp_1999.aspx (accessed 10 March 2015).

Telecom Regulatory Authority of India (TRAI) (2015b) The Indian Telecom Services Performance Indicator, New Delhi [online] http://www.trai.gov.in/WriteReadData/PIRReport/Documents/ IndicatorReports29012015.pdf (accessed 12 February 2015).

Telecommunications Regulatory Commission of Sri Lanka (2014) Corporate Information, TRC, Colombo [online] http://www.trc.gov.lk/2014-05-13-12-58-57/corporate-information.html (accessed 23 March 2015).

UN Statistics Division (2015) National Accounts Main Aggregates Database, United Nations, New York [online] http://unstats.un.org/unsd/snaama/selbasicFast.asp (accessed 30 March 2015).

United Nations Conference on Trade and Development (UNCTAD) (2011) Who is Benefitting from Trade Liberalization in Bhutan? A Gender Perspective, New York and Geneva.

United Nations Public Administration Network (UNPAN) (2015) Information Technology Policy of Pakistan-Providing an Enabling Environment for IT Development, New York [online] http://unpan1.un.org/intradoc/groups/public/documents/APCITY/UNPAN015892.pdf (accessed 12 January 2015).

World Bank (1999) World Development Report, Oxford University Press, New York. 


\section{Notes}

1 GSLI is a composite index that captures the off shoring prospect in more than 50 countries (55 in 2016). Three major categories used are financial attractiveness (40\%), people skills and availability $(30 \%)$, and business environment $(30 \%)$. These three major categories are further divided into 11 sub-categories and the sub-categories are divided into 38 metrics. The index particularly.

2 The data for exports and imports of services (in thousands US\$) have been taken from the International Trade Centre (ITC), and GDP data from the UN Statistics Division in US\$ at constant 2005 prices. 